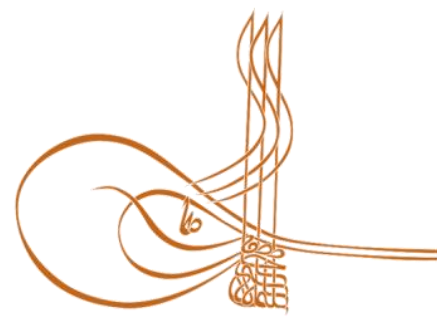

www.turkishstudies.net/economy
Turkish Studies - Economics, Finance, Politics

eISSN: $2667-5625$

Research Article / Araștırma Makalesi

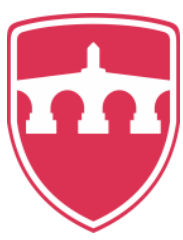

INTERNATIONAL BALKAN

UNIVERSITY

Sponsored by IBU

\title{
Menderes Dönemi Türk Dış Politikasının NATO Üyeliği ve Bağdat Paktı’nın Kurulması Örnekleri Üzerinden Analizi
}

\author{
Analysis of the Turkish Foreign Policy of the Menderes Period on Nato Membership and the \\ Foundation of the Baghdad Pact
}

\begin{abstract}
Sami Kiraz ${ }^{*}$
Abstract: To make close relations with the Western alliance and Western governments has been determined as a major trend in foreign policy by the Republic of Turkey since the establishment. This approach is based on the belief that Turkey could be one of the developed nations and eliminate threats with this strategy. The peak point of the implementation of this strategy was the Menderes period. Menderes and the Democratic Party, who took over after the single-party rule, considered it vital to act together with the US in their foreign policy. Trying to increase its influence in domestic politics on the one hand, Menderes also carried out its foreign policy on behalf of both its own and country's political survival. Menderes, has a significant impact on the formation of foreign policy in the next period, reached his aim, through the use of insistent methods, and Turkey has become a part of the Western bloc. In this study, the foreign policy of the Menderes period, which constitutes the starting point of being in the Western alliance and the most obvious logic of Turkish foreign policy, will be analyzed. For this, firstly the international policy conditions of the period will be discussed and then Menderes' foreign policy approach will be examined. Later, foreign policy implementations during the NATO membership and the establishment of the Baghdad Pact, which can be accepted as concrete indicators of Menderes' foreign policy, will be evaluated. Finally, it will be completed with the making an inference about Turkish Western-based foreign policy.
\end{abstract}

Structured Abstract: To make close relations with the Western alliance and Western governments has been determined as a major trend in foreign policy by the Republic of Turkey since the establishment. This approach is based on the belief that Turkey could be one of the developed nations and eliminate threats with this strategy. The peak point of the implementation of this strategy was the Menderes period. It seems important to reexamine the Menderes and Democratic Party, which are very important in both Turkish political life and foreign policy, in a period when the West / US alliance was discussed loudly and to analyze how the foundations of the pro-Western foreign policy were laid. In this study, the factors that determine the foreign policy of the Menderes period were analyzed. In this context, in the first part of the study, conditions of

\footnotetext{
* Dr. Öğr. Üyesi, Hitit Üniversitesi, İktisadi ve İdari Bilimler Fakültesi, Uluslararası İlişkiler Bölümü

Asst. Prof. Dr., Hittt University, Faculty Of Economics And Administrative Sciences/Department Of International Relations ORCID 0000-0002-6987-9856

samikiraz@gmail.com

Cite as/ Atıf: Kiraz, S. (2020). Menderes Dönemi Türk Dış Politikasının Nato üyeliği ve Bağdat Paktı'nın kurulması örnekleri üzerinden analizi, Turkish Studies - Economy, 15(1), 309-321.
} https://dx.doi.org/10.29228/TurkishStudies.41483

Received/Geliş: 26 January/Ocak 2020

Accepted/Kabul: 25 March/Mart 2020

Copyright $($ INTAC LTD, Turkey 
international politics of the period and external factors of Turkey's foreign policy were examined. Then Menderes' perspective about both foreign policy and Turkey's possible position on the world was discussed. Later, Menderes' foreign policy approach was examined through two main developments of the period which are NATO membership and the establishment of the Baghdad Pact. Eventually, study has been completed with an inference that the period of being incorporated into the Western alliance is important for working current Turkey's foreign policy.

In Adnan Menderes' period, it seems that the general perceptions of the leader are very determining in Turkish foreign policy. Menderes, who is called pro-Western or even "Americanist", has always acted with this logic in his foreign policy. Turkey's relations and the institutional cooperation with the West reached its peak during this period. Turkey often act out of this heritage in the later eras. Turkey continues to be affected from, as examined in this study, the results of two major foreign policy events which are NATO membership and the establishment of Baghdad Pact, of Menderes' period. NATO has provided a comprehensive military security umbrella to Turkey and Turkey has been able to overcome traditional Russian threat during the Cold War. Moreover, Turkey was able to increase its military capacity thanks to NATO and NATO has been one of the factors that play a role in Turkey's becoming a major military power. However, Turkey also has been faced with the negative consequences because of being a US ally. Especially in autonomous foreign policy implementation, this issue has had preventive consequences. Cold War conventional solid alliance systems has made Turkey's pro-Western movement is often mandatory. Although its results are short-term effective compared to NATO, the Baghdad Pact has had similar effects on Turkish foreign policy. Turkey, as a partner of Western military alliance, tried to increase political importance of itself by Baghdad Pact. However, this initiative also led to a restrictive effect for Turkey's foreign policy. Turkey was accused for being the West's spokesman in the region, thus it was unable to conduct regional relations as it wishes.

As a state who wants to get rid of traditional limitations in the 21 st century, Turkey's main problems, in the process, has been based on Western-oriented foreign policy history. Turkey, in order to peel from this identity has made a serious effort. However, the crises (related or not with Turkey) harmed process permanently and significant progress has not been achieved. At a time when the end of the first quarter of the century, Turkish foreign policy had to deal with similar issues and problems. On the one hand the questioning of the US alliance and on the other hand the historical obstacles about the regional formations are to create problems for Turkey's long-term foreign policy objectives.

It is a fact that the foundations of this restrictive process were laid during the Menderes period, with the foreign policy events especially such as NATO membership and the Baghdad Pact initiatives. Turkey has showed a significant effort to become an important partner of Western bloc during this period which is shaped by Menderes' initiatives. In this context, it seems important to look back to the beginning of the story while analyzing the questioning of the Turkey's membership of Western ally in the 2010s. Using this framework is considered to be an important requirement for comprehensive assessments about the discussion on relationship between Turkey and Western alliance.

Keywords: Turkish Foreign Policy, Menderes, NATO, Baghdad Pact, Western-based Foreign Policy

Öz: Türkiye Cumhuriyeti, kuruluşundan itibaren dış politikasında Batı ittifakı ve Batılı devletlerle yakın ilişkiler kurmayı büyük ölçüde temel eğilim olarak belirlemiştir. Bu yaklaşımın temelinde ise Türkiye'nin bu stratejiyle birlikte gelişmiş devletler arasında yer alabileceği ve tehditleri bertaraf edebileceği inancı yatmıştır. Söz konusu stratejinin uygulanmasının zirve noktası da Menderes dönemi olmuştur. Tek parti iktidarı sonrasında yönetimi devralan Menderes ve Demokrat Parti, dış politikasında ABD ile birlikte hareket etmeyi hayati önemde görmüş ve uygulamalarını bu bağlamda şekillendirmiştir. Bir taraftan iç siyasetteki etkisini arttırmaya çalışan Menderes, diğer taraftan da hem kendi hem de ülkenin siyasi bekası adına dış politikasını yürütmüştür. Kendisinden sonraki dönemin dış politika koşullarının oluşmasında da önemli bir etki sahibi olan Menderes, amacına ısrarlı yöntemler kullanmak suretiyle ulaşabilmiş ve Türkiye'yi Batı bloğunun bir parçası haline getirebilmiştir. Bu çalışmada, Türk dış politikasının en bariz hareket mantığı olan Batı ittifakı içerisinde yer almanın başlangıç noktasını oluşturan Menderes döneminin dış politika analizi yapılacaktır. Bunun için öncelikle dönemin uluslararası politika koşulları ele alınacak ve daha sonra Menderes' in dış politika yaklaşımı incelenecektir. Daha sonra, Menderes'in dış politikasının somut göstergeleri olarak kabul edilebilecek olan NATO üyeliği ve Bağdat Paktı’nın kurulması süreçlerindeki dış politika uygulamaları değerlendirilecektir.

Turkish Studies - Economy, 15(1) 
Nihayetinde, Türkiye'nin Batı temelli dış politikasına yönelik tartışmaların, döneme dair çalışmaları temel alarak yürütülmesine yönelik çıkarımda bulunarak çalışma tamamlanacaktır.

Anahtar Kelimeler: Türk Dış Politikası, Menderes, NATO, Bağdat Paktı, Batı Temelli Dış Politika

\section{Giriş}

Türkiye Cumhuriyeti, kuruluşundan itibaren dış politikasını büyük ölçüde Batı ittifakıyla ve Batılı ülkelerle yakın ilişkiler kurmak üzerine kurgulamıştır. Devletin kuruluş ideolojisi ve vizyonu itibarıyla gelişmenin ve kalkınmanın bu yolla gerçekleşebileceği inancı, süreç içerisinde stratejilerde ve kullanılan araçlarda değişimler gözlenmekle birlikte günümüze kadar devam etmiştir. Bu politikaların en somut göstergeleri de Türkiye'nin Batı bloğu içerisinde yer alması ve bununla birlikte, NATO ve AT/AB üyelik süreçleri olmuştur. Farklı ideolojik ve siyasal kökenden gelen iktidarlar pek çok konuda ayrışırken Türkiye'nin Batı ittifakı içerisinde yer alması ve uzun vadeli politikaların sürdürülmesi noktasında radikal değişimler söz konusu olmamıştır.

Türkiye'nin bu genel politikasının en bariz çıktılarla tepe noktasına ulaştığı dönem de üzerine yapılan tartışmalar devam etmekle birlikte, Menderes dönemi olmuştur. Türk siyasal hayatı açısından da önemli bir kırılma dönemi olan 1950-1960 yılları arası Demokrat Parti iktidarı, tek parti döneminin sonu anlamı da taşımıştır. Diğer taraftan yeni bir uluslararası güç mücadelesinin başlangıç yıllarına da denk gelen Menderes döneminde Türkiye, keskin bir Batı müttefiki haline gelmiş ve Soğuk Savaş'ın Batı kutbunun önemli bir üyesi olmuştur.

Hem Türk siyasal hayatında hem de dış politikasında böylesi önemli bir konumda bulunan Menderes ve Demokrat Parti'nin Batı/ABD müttefikliğinin yüksek sesle tartışıldığı bir dönemde yeniden incelenmesi ve Batı yanlısı dış politikanın temellerinin nasıl atıldığının analiz edilmesi önemli görünmektedir. Bu çalıșmada söz konusu analiz yapılarak Menderes dönemi dıș politikasını belirleyen etmenler ele alınacaktır. Bu bağlamda, çalışmanın ilk bölümünde dönemin uluslararası politika koşulları incelenerek ve Türkiye'nin dış politikasına yönelik dış kaynaklı faktörler analiz edilecektir. Daha sonra, dönemin dış politikasının en üst düzey karar mercii olan Menderes'in dış politikaya ve Türkiye'nin kendisini nasıl konumlandırması gerektiğine dair bakış açısı tartışılacaktır. Daha sonra, Menderes'in dış politika yaklaşımı dönemin iki temel gelişmesi olan NATO üyeliği ile Bağdat Paktı'nın kurulması örneklerinden incelenecektir. Nihayetinde, Türkiye'nin Batı ittifakına dahil olma sürecinin güncel dış politika tartışmalarındaki önemine dair çıkarımlarla çalışma tamamlanacaktır.

\section{Dönemin Uluslararası Politika Koșulları}

İkinci Dünya Savaşı'nın sona ermesiyle uluslararası sistemin çok kutuplu yapısı değişmiş ve iki büyük güç olarak kalan ABD ve SSCB öncülüğünde iki kutuplu bir yapı ortaya çıkmıştır. Batı ve Doğu olarak da adlandırılan bu iki yeni kutup, savaş sonrası süreçte uluslararası sistemin dinamiklerini belirlemiştir. 1945 y1lında kurulan Birleşmiş Milletler yeni dönemin uluslararası örgütü olmuş, ekonomik sistem ABD öncülüğünde kurgulanan Bretton Woods sistemi olurken IMF ve Dünya Bankası gibi kurumlarla bu sistem yürütülmüştür. Ancak Soğuk Savaş döneminin en belirgin niteliği, askeri ittifaklar düzeyinde ortaya çıkmıştır. Bir tarafta ABD öncülüğündeki NATO (1949) devletleri, diğer tarafta Sovyetlerin başını çektiği Varşova Paktı (1955) dünyayı keskin hatlarla birbirinden ayırmıştır.

İkinci Dünya Savaşı sırasında ortak düşmana (Almanya) karşı birlikte savaşan ABD ve SSCB, savaş öncesi dönemin diğer büyük güçleri olan İngiltere ve Fransa'nın bu niteliklerini kaybetmeleriyle iki süper güç olarak ortaya çıkmışlardır. Ancak aralarındaki derin ideolojik ayrım, bu iki devletin birlikte hareket etme imkanını ortadan kaldırırken süreç içerisinde birbirlerini tehdit olarak algılayarak karşılıklı bir mücadele süreci başlamıştır. ABD, komünizmi bir tehdit olarak 
görmüş, özellikle Avrupalı devletlerin bu akımdan etkilenerek komünist ideolojiyi benimsemelerini engellemek istemiştir. Bunun için savaşta harap olan bu devletlere Marshall Planı ${ }^{1}$ ve Truman Doktrini $^{2}$ gibi çeşitli yardım organizasyonları düzenleyerek bu devletlerle ilişkilerini kurgulamıştır. Bununla birlikte, artan bir Sovyet tehdidi algisı pompalanarak, SSCB ilk olarak fikirsel anlamda çevrelenmeye çalışılmıştır. Daha sonra çevreleme politikası ${ }^{3}$ hayata geçirilmiş; NATO kurularak SSCB toprakları, ABD öncülüğündeki askeri ittifaklar marifetiyle kuşatılmıştır. SSCB tarafında da ABD'nin kendisine karşı izlediği politikalara cevap olarak benzer bir eğilim söz konusu olmuştur. Özellikle yerli komünistlerin iktidarları ele geçirmeleriyle komünistleşen Doğu Avrupalı devletler, Kominform ve COMECON gibi yapılarla Sovyetlere yaklaştııılmış, daha sonra da Varşova Paktı ile askeri yapılanma sağlanmıştır. ${ }^{4}$

Soğuk Savaş'ın ilk evresi olarak da kabul edilen bu dönem, iki kutup arasında ciddi gerilimlerin yaşandığg ve amansız bir güç mücadelesine girişildiği bir süreç şeklinde geçmiştir. Çoğu zaman aradaki gerginliğin sıcak çatışma ortamına dönmesi riski, dünya kamuoyu tarafından korkuyla takip edilmiştir. Böylesi bir ortam, bütün dünyayı fazlasıyla etkilemiş, devletler taraf seçmek durumunda kalmış ve politikalarını da seçilen tarafın beklentilerini karşılayacak şekilde revize etmek gerekliliğiyle karşılaşmışlardır.

Türkiye için de durum yukarıda anlatılanlara benzer şekilde olmuştur. Katı ittifak sistemleri ve birlikte hareket etme gerekliliği Türkiye'yi de içine almıştır. İkinci Dünya Savaşı sırasında savaş dışı konumunu koruyabilen Türkiye için savaş sonrası dönem oldukça sıkıntılı başlamıştır. Öncelikle savaş biter bitmez Sovyetler Birliği'nin toprak talebiyle yüzleşmek zorunda kalan Türk dış politikası karar alıcıları, yaşanan uluslararası gelişmeler neticesinde zorlu bir dış politika yönetimi yürütmüşlerdir (Esmer ve Sander, 1996:204). Sovyet tehdidi nedeniyle Batı ittifakına yanaşan Türkiye, dış yardımlardan da daha fazla faydalanmak adına dış politikasında ABD merkezli hareket etmeyi tercih etmiştir (Yıldız, 2017:307). Bu bağlamda, Türkiye, Marshall Yardımı ve Truman Doktrini ile ABD ile iyi ilişkiler kurarken Batı'nın askeri ittifakının da içinde yer alabilmek adına Kore Savaşı'na (1950-1953) katılmak durumunda kalmıştır.

\section{Menderes'in Dış Politika Yaklaşımı}

Türkiye'nin çok partili hayata geçmesiyle birlikte kurulan Demokrat Parti (7 Ocak 1946), kuruluşundan dört yıl sonra 27 yıllık tek parti iktidarını sona erdirmiş ve 14 Mayıs 1950 seçimlerini kazanarak iktidarı İsmet İnönü ve CHP'den devralmıştır. Başbakanlık görevine gelen Adnan Menderes, 10 yıl sürecek iktidarı boyunca devleti yöneten isim olmuştur. Öncelikle, Türkiye Cumhuriyeti tarihi için çok önemli bir kırılma olarak kabul edilebilecek olan Demokrat Parti ve Adnan Menderes'in iktidara gelişi, hem iç politikada hem de dış politikada etkisini ziyadesiyle hissettirmiştir. Her ne kadar siyasi kariyerine CHP içerisinde başlamış ve İnönü’nün milletvekili olarak görev verdiği bir isim de olsa Adnan Menderes, parti içinde muhalefetiyle dikkat çekmiş ve nihayetinde CHP'den ayrılarak Demokrat Parti'yle birlikte kendi yolunu belirlemiştir. Bu süreç, 1950 seçimlerinin kazanılarak tek parti yönetiminin son bulmasına kadar devam etmiştir (Ahmad ve Turgay, 1976:70).

\footnotetext{
${ }^{1}$ İkinci Dünya Savaşı sonrasında ekonomileri çöken Avrupa Devletleri’nin ABD yardımlarıyla yeniden güçlü ekonomilere sahip olmalarını amaçlayan, bu sayede de Amerikan ekonomik siteminin güçlenmesini sağlaması planlanan yardım programıdır. 16 ülkenin dahil edildiği bu planla ABD Avrupa devletlerine 50 milyar dolar ekonomik yardımda bulunmuştur (Hogan, 1987).

${ }^{2}$ Yalnızca Türkiye ve Yunanistan'ın dahil edildiği proje kapsamında, bu iki ülkenin Sovyetler Birliği karşısında güçlendirilerek Batı Bloku yanlısı politika izlemeleri amaçlanmıştır.

${ }_{3}^{3}$ Sovyetler Birliği'nin etrafında ABD müttefikleri sayesinde bir güvenlik çemberi oluşturma politikasıdır. Bu bağlamda, özellikle Türkiye bu planın önemli bir parçasıdır. Bu politikayla, ABD, SSCB'nin yakın çevresinde üsler edinerek nükleer silahları buralara yerleştirmeyi ve dönem şartları itibarıyla uzun menzil füze eksikliğini bu şekilde gidermeyi amaçlamıştır (Young ve Kent, 2013).

${ }^{4}$ Soğuk Savaş dönemi ile ilgili ayrıntılı kaynakça için bkz. (Young ve Kent, 2013); (Sibley, 1998); (Sewell, 2002); (Harper, 2011); (Crockatt, 1995). (Wenger ve Zimmermann).
} 
Menderes, gerek iktidara geliş biçimi itibarıla gerekse de döneminin uluslararası konjonktürü itibarıyla devlet yönetiminde olduğu gibi Türk dış politikasında da oldukça önemli bir rol oynamıştır. Menderes'in Türk dış politikasının temel belirleyicisi olarak dış politikaya dair genel yaklaşımı ele alındığında ilk olarak, Menderes'in dış politikaya yönelik bakışını şekillendiren en önemli sürecin henüz muhalefetteyken işlemeye başladığı söylenebilir. Demokrat Parti kuruluş tarihi itibarıyla İkinci Dünya Savaşı'nın sona erdiği, Almanya'nın tamamen güçsüz bırakıldığı, İngiltere ve Fransa'nın eski güçlerini kaybettiği artık yalnızca ABD ve SSCB'nin büyük güçler olarak kaldığı bir uluslararası sistemin ortaya çıktığı bir döneme denk gelmiştir. Yukarıda bahsedilen savaş sonrası süreçte yaşanan Sovyet tehdidi ise Türkiye'yi ABD'ye yaklaştırmıştır (Göktepe ve Seydi, 2015: 206207).

Menderes de bu şartlar altında Türkiye'nin kalkınmasının ve gelişmesinin ancak ABD ile daha yakın ilişkiler kurmaktan geçtiğini düşünmüştür. $\mathrm{Bu}$ nedenle, Menderes'in dış politika tutumunun genellikle "Amerikancıllk" olarak tanımlanması söz konusu olmuştur (Yetener, 2007: 50). Öyle ki Sovyet tehdidi sonrası ABD ile yakın ilişkiler kuran İnönü yönetimini gelen yardımlar ve sıkı işbirliğine rağmen Batı ile ilişkilerde eleştiren Menderes, başta NATO'ya üyelik olmak üzere iktidarın çok pasif davrandığını savunmuştur. Menderes'e göre "savaş sonunda iki büyük blok ortaya çıkmışıır ve tarafsız kalmak mümkün değildir. Dolayısıyla Sovyet blokuna giremeyeceğimize göre Amerikan blokuna katılmak bir zorunluluktur" (Eroğul, 1998:92-93).

Menderes, uluslararası konjonktürde, cumhuriyetin kurulmasından bu yana yaşanan değişikliği şu şekilde açıklamıştır:

“o tarihlere nazaran bugün Avrupa'da kuvvetler dengesi kökünden değişmiştir. Faşist yönetimler ortadan kalkmış, buna dayanan dünya sistemi de yıkılmıştır. Almanya artık askeri bir kuvvet değildir, o devrin bağımsız devletleri olan Romanya, Bulgaristan, Polonya, Çekoslovakya ve Macaristan da demir perdenin arkasında kalarak Sovyet Rusya'nın eline geçmişlerdir. Japonya da dünya siyasetinde oynadığı önemli rolünden uzaklaşmıştır. ABD'nin ise, dünya barışını korumak adına Avrupa'da ve Yakın ve Orta Doğu'daki rolü bir Avrupa devletinden daha önemli hale gelmiş, bir zamanların Avrupa dengesi olan milletlerarası bir politika yerini tüm dünyayı içine alan ve ideolojik esaslara göre ayrılan bir güçler karşılaşmasına bırakmıştır. Yani dünya barışı artık bir bütün haline gelmiştir." (Yetener, 2007: 51)

Dış politikada başarılı olmanın yolunu ABD ile daha yakın ilişkiler kurmak ve Batı blokuna dahil olmak olarak gören Menderes, iktidara geldikten sonra da bu minvalde uğraşmıştır. Menderes'in ABD'ye bu kadar yakın olmasının nedenlerinden biri de ABD'nin demokratik ilkeleri de temsil ettiğini düşünmesi ve tek parti rejiminin hakim olduğu bir devlette muhalefet yaparak iktidarı alması olmuştur. Öyle ki o dönem ABD ile kurulacak yakın ilişkilerin temel şartlarından birisi olarak demokratik rejime sahip olmak genel kabul gören bir olgu olmuştur.

Dış politika hareket mantı̆̆ olarak ele alındığında, Menderes döneminin kendinden önceki Atatürk ve İnönü dönemleriyle ciddi manada farklılaştığı görülmektedir. Öncelikle büyük boyutlu ittifaklara girmeme geleneği ${ }^{5}$, Menderes'in yukarıda da bahsedildiği üzere temelden karşı çıktığ 1 bir husus olmuştur. Bilhassa, NATO'ya üye olabilmek adına önemli dış politika adımları atan Menderes, başta güvenlik alanı olmak üzere siyasi, ekonomik ve kültürel alanlarda da Batı kutbuna dahil olmaya çalışmıştır. Bunun karşılığı olarak, SSCB ile tüm siyasi ilişkiler kesilmiş ve tek taraflı bir dış

\footnotetext{
${ }^{5}$ Atatürk'ün dış politika ilkelerinin en önemlilerinden olan askeri ittifaklardan ve bağlantılardan kaçınmanın gerekçesini Akşin şu şekilde açıklamaktadır: "Her ittifak, bu ittifakın sarih veya zımni olarak aleyhine müteveccih olduğu devlet veya devletler nezdinde şüphe ve rahatsızlı, hatta güvensizlik doğurur ve binnetice, mukabil ittifak veya kombinezonları tahrik eder. $\mathrm{Bu}$ ise, herkesle iyi geçinmek isteyen ve kimsenin toprakları ve menfaatleri aleyhinde art düşünce ve davranış1 olmayan Türkiye'nin ana dış politika ilkelerine aykırı olurdu.” (Akşin, 1991: 123).
} 
politikaya geçilmiştir. Eroğul'a (1998) göre Menderes geleneksel denge politikasını bırakmış ve ABD endeksli bir dış politika izleyerek ülkenin güvenliği ABD'nin güvenlik çemberinin bir parçası haline gelmiştir. Atatürk'ün temel görüşü ulusal bağımsızlık ve dış güvenlik, bağımlı bir güvensizliğe dönüşmüştür. Sovyet düşmanlığ tamamen benimsenmiş, kuzey sinırları da tehlikeye atılmıştır. Ayrıca Bağdat Paktı yüzünden Arap ülkeleriyle sorunlar yaşanmış ve bu devletlerin Türkiye'ye şüphe ile bakmaları sonucu yaşanmıştır (266-267).

Menderes'in dış politikaya yönelik algılarının ve uluslararası politika gelişmelerini nasıl görüp değerlendirdiğinin daha net ortaya konması adına dönemin dış politika uygulamalarından bazılarını incelemek bütünlük adına faydalı olacaktır. Bu bağlamda, ilk olarak Türkiye'nin bütün devlet sistematiğini ve dış politikasını belirleyen gelişmelerin başında gelmesi itibarıyla NATO'ya üyelik ilk olarak incelenecektir. İkinci örnek olay da bir diğer ittifak oluşumu olarak, Türkiye'nin başta kendi coğrafyası olmak üzere dünyaya net bir mesajı olarak algılanabilecek olan Bağdat Paktı'nın kurulması sürecinde izlenen dış politikadır

\section{NATO Üyeliği}

Türkiye'nin NATO'ya üyeliği konusu, İkinci Dünya Savaşı’nın sona ermesinden sonra hem uluslararası alanda hem de Türkiye'nin kendi dış politika yöneliminde yaşanan gelişmelere istinaden, bir süreç halinde ortaya çıkan önemli bir gelişme olmuştur. İkinci Dünya Savaşı sonrasında Batı dünyası için en önemli tehdit olarak SSCB ortaya çıkmıştır. Üstelik savaş sonrası süreçte Sovyetler'in nüfuz alanlarını sürekli olarak genişletmesi ve son olarak 1948 yılında Berlin'i işgal etmesi, Batı Avrupa devletlerini ABD'nin de desteğini alacakları yeni savunma mekanizmaları arayışına itmiştir. Bu bağlamda, 1948 yılında İngiltere, Fransa, Belçika, Hollanda ve Lüksemburg, Batı Avrupa Birliği Savunma Örgütü'nü kurmuşlardır. Buna göre, taraflar içlerinden birisinin Avrupa'da uğrayacağı bir saldırıda hep birlikte hareket edeceklerdi ve oybirliği durumunda Birliğe başka üyeler de alınabilecekti. Fransa Dışişleri Bakanı George Bidault, bu birliğin ABD ve diğer Avrupa devletlerini de içine alacak şekilde genişletilerek ortak bir savunma sistemine evrilmesini önermiş ve NATO'nun temelleri atılmıştır (Bağc1, 2001: 9-10). Nihayetinde, NATO (Kuzey Atlantik Antlaşması Örgütü) 4 Nisan 1949 tarihinde Belçika, Danimarka, Fransa, İngiltere, İzlanda, İtalya, Kanada, Lüksemburg, Hollanda, Norveç, Portekiz ve ABD’nin kuruculuğunda Kuzey Atlantik Antlaşması imzalanarak kurulmuştur.

Türkiye, NATO kurulurken bu örgüte katılmak istediğini çeşitli yollarla bildirmiş ancak davet edilmemiştir. Bu sırada iktidarda bulunan CHP'nin Dış İşleri Bakanı Necmettin Sadak, Avrupa Ekonomik İşbirliği toplantısında bu isteklerini dile getirmiş hatta bunun reddedilmesi durumunda Türkiye, Yunanistan, İtalya, Fransa ve İngiltere'nin içinde olduğu ve NATO ile bağlantılı bir Akdeniz Paktı önerisinde bulunmuştur. Türkiye'nin önerileri kabul görmese de 11 Mayıs 1950 tarihinde CHP döneminin sonlarında NATO'ya üyelik başvurusunda bulunulmuş ancak bir karşıllık alınamamış ve konu Demokrat Parti dönemine kalmıştır (Oran, 2006: 545).

Menderes NATO'ya katılmayı hükümetin temel ve öncelikli hedeflerinden birisi olarak görmüştür. Bu doğrultuda, her firsatta Türkiye'nin Batı'nın güvenliği için ne denli önemli olduğunu ve ancak Türkiye'nin de dahil olduğu bir ortak savunma organizasyonunun SSCB'nin durdurulmasında tam manasıyla yeterli olacağını vurgulamıştır (Yetener, 2007: 73). CHP tarafından yapılan ilk başvurunun olumlu sonuçlanmamasının ardından, Türkiye, 11 Ağustos 1950'de NATO'ya üyelik için ikinci başvurusunu yapmıştır. Bu sırada Amerikalı yetkililerce Türkiye ve Yunanistan'a ilerleyen süreçte tam üye olarak tanınacakları ama ilk etapta ortak üyelik şeklinde çeşitli önerilerde bulunsa da Türkiye "ikinci sınıf üyelik" statüsünü reddetmiştir. Türkiye'nin üyelik talebi, 1950 yılı Eylül ayında yapılan NATO Bakanlar Konseyi’nde görüşülmüş ve reddedilmiştir. Ancak çeşitli planlamalara dahil olmak üzere Yunanistan'la birlikte Türkiye, Konsey çalışmalarına davet edilmiştir (Hale, 2000: 118). Bu sırada ABD, NATO'ya üye olmayan Türkiye, Yunanistan ve Mısır ile İngiltere ve Fransa'nın dahil olacağı bir “Akdeniz Paktı” kurulması fikrini ortaya atmıştır. 
Türkiye, bu öneriyi NATO'ya katılmanın bir adımı olarak gördüğü için olumlu değerlendirmiştir ancak paktın kurulabilirliği konusunda şüpheli yaklaşmıştır. Bunun nedeni, İngiltere ve Mısır'ın aynı pakt içinde yer almasının olanaksız olacağı düşüncesi olmuştur (Oran, 2006: 548).

Türkiye, NATO'ya üye olmaya çalışırken bu sırada yaşanan diğer gelişmeleri de bu süreçle birlikte değerlendirmiştir. Şöyle ki, SSCB'ye karşı bir çevreleme politikasına girişen ABD, bu politikanın başarılı olabilmesi adına ve olası bir Sovyetler'in Avrupa'yı işgal politikası sırasında, çeşitli bölgelerde hava üslerine ihtiyaç duymaktaydı. Türkiye'den bu konuda talepte bulunan ABD, Türkiye'den NATO'ya üyelik şartıyla karşılaşmıştır (Tuncer, 2013: 36). Bunun yanı sıra, 1950 yılında başlayan Kore Savaşı'nda ABD'nin girişimleriyle Birleşmiş Milletler'den Kuzey Kore'yi durdurmak adına üyelere çağrı yapan bir karar çıkmıştır. Bu çağnya ilk yanıtı veren ülke Türkiye olmuştur. Menderes, 5000 kişilik bir birliğin savaşa gönderilmesi hususunda önemli bir inisiyatif almıştır. Öyle ki, bu karar muhalefet dahil edilmeden hatta Dışişleri Bakanı dahi yeterince bilgilendirilmeden alınmıştır. ${ }^{6}$ Menderes tarafından reddedilmekle birlikte, Türkiye'nin Kore'ye asker göndermesini NATO'ya üyelik şartı ile gerçekleştirildiği çok tartışılan bir husus olmuştur. ${ }^{7} \mathrm{Bu}$ konuda net bilgiler olmadığından böyle bir iddiada bulunmak yerine, bu sürecin ABD'deki Türkiye algılarını etkilediğini ve NATO'ya kabul sürecinde olumlu etki yaptığı belirtilebilir.

ABD’nin, Türkiye'nin NATO’ya üyeliğine sıcak bakmaya başlamasıyla birlikte, süreç Türkiye için olumlu ilerlemeye başlamıştır. Bu sırada, NATO Başkomutanı General Dwight Eisenhower, Ocak 1951'de Başkan Truman'a gönderdiği mesajda olası bir savaş durumunda, Türkiye'nin coğrafi konumu itibarıyla Yunanistan'la birlikte hayati bir öneme sahip olacağı ve ancak Türkiye'nin kesin bir güvenlik taahhüdü verildiğinde bu plana destek olacağını belirtmiștir. Yugoslavya'nın Kominform'dan çıkartılması da bu sürece destek olmuş ve Türkiye'nin önemi artmıştır. Bu gelişmelerden sonra Türkiye'ye üyelik yolu açılmıştır. Üye ülkelerin Türkiye'ye bakışı olumlu yönde gelişirken İngiltere, kurulmasını istedi "Ortadoğu Komutanlığı" nedeniyle üyeliğe karşı çıkmaya devam etmiştir. Türkiye'nin üye olma durumunda Ortadoğu güvenlik sistemlerinde yer alacağını taahhüt etmesi bu sorunu da çözmüştür ve Mayıs 1951'de Türkiye, Yunanistan'la birlikte NATO'ya tam üye olma amacıyla davet edilmiştir. Bu sırada, Mısır'ın Ortadoğu Komutanlığı tasarısını reddetmesi sonucu İngiltere'nin planı ortadan kalkmış ve Türkiye ikinci bir yükümlülük altına girmeden 1952 yılında NATO'ya üye olmuştur (Hale, 2000: 118-119).

Türkiye'nin NATO'ya üye olma ve ABD'nin de Türkiye'nin üyeliğini desteklemesi hususlarında çeşitli nedenler ön plana çıkmıştır. ABD, Sovyetleri çevreleme politikasının önemli bir ayağını oluşturacağı beklentisiyle Türkiye'nin ittifaka dahil edilmesi gerektiğini ve Türkiye topraklarında edineceği askeri üs sayesinde Sovyet tehdidini dengeleyebileceğini düşünmüştür (Bilge-Criss, 2012: 15). Ayrıca, Türkiye'nin Ortadoğu bölgesine olan coğrafi ve kültürel yakınlığı sayesinde Türkiye üzerinden bu devletlerle yakın ilişkiler kurma beklentisi de ABD'yi bu yönde bir politika izlemeye itmiştir. Türkiye tarafında ise, Sovyet tehdidine karşı en güçlü devletin ABD olduğu algısı ve bu devletle birlikte hareket etme isteği ağır basmıştır. Menderes'in demokrasinin gereği olarak Batılı kurumlara üyeliği gerekli görmesi ve ancak bu yapılar içerisinde kendi iktidarını da sürdürebileceği düşüncesi önemli olmuştur. Bir diğer neden olarak da İkinci Dünya Savaşı sonrası gelmeye başlayan Amerikan askeri ve ekonomik yardımlarının Türkiye'nin NATO'ya üye olmasıyla devam edeceği beklentisi ön plana çıkmıştır (Tuncer, 2013: 35-38).

Türkiye'nin NATO'ya üyeliği sürecinde Menderes'in izlediği dış politika genel olarak değerlendirildiğinde, Menderes tarafindan NATO’ya yüklenen anlam ve dönemin uluslararası

\footnotetext{
${ }^{6}$ Türkiye'nin Kore Savaşı'na katılma kararı vermesiyle ilgili ayrıntılı bilgi için bkz. (Bağc1, 2001: 19-22).

${ }^{7}$ Türkiye'nin Kore meselesine ilgisiz kalmasının ileride Türkiye'ye yönelik yaşanacak bir Sovyet saldırısında Türkiye'nin yalnız kalması sonucunu doğuracağı endişesi Türkiye tarafında hakim olmuştur. Bununla birlikte, savaşa katılmanın NATO başvurusunun kabulünde etkili olacağı da düşünülmüştür. Asker gönderme kararı alınmasından kısa süre sonra NATO’ya girme başvurusunun yapılmasının da bunun göstergesi olduğu iddia edilebilir (Yetener, 2007: 74).
} 
politika gelişmelerinin büyük ölçüde belirleyici olduğu ortaya çıkmaktadır. Geleneksel dış politika çizgisine zıt bir davranış olan Batı askeri ittifak sistemine dahil olmak, çarpıcı bir dış politika uygulaması olmuştur. Böyle bir yapının içerisine girmek de ancak liderin kararlılığı ile mümkün olmuştur. Türkiye'nin güvenliğini, iktidarın sürekliliği ile bir arada değerlendirerek Batı kutbuna dahil olmayı bir mecburiyet olarak gören Menderes, politikalarını buna göre belirlemiştir. NATO dışında kalmanın Türkiye'yi Sovyet tehdidi ile karşı karşıya bırakacağını düşünen Menderes, bu motivasyonla hareket etmiştir. Bu uğurda 1 srarcı bir politika izlenerek Türkiye'ye yönelik algılar değiştirilmeye ve ABD ikna edilmeye çalışılmıştır. Dönemsel gelişmeler de bu bakış açısından yorumlanarak yine geleneksel dış politika çizgisinin dışına çıkılmış ve sınır ötesine Türk askeri gönderilmiştir. İngiltere'nin talepleri de makul düzeyde kabul edilmiş ancak şarta bağlanarak lehte kullanılmıştır. Sonuç olarak, NATO'ya üye olmayı dış politika hedefi olarak belirleyen Menderes, iç politikayı da bu konuya kanalize etmiş ve istediğini elde etmiştir.

\section{Bağdat Paktı'nın Kurulması}

Menderes'in genel dış politika uygulamalarında da benzer tutuma sahip olduğu kabul edilebilir. Bunun bir diğer örneği de Bağdat Paktı olmuştur. Ortadoğu bölgesinde ortak güvenliğin sağlanması amacıyla girişilen bir proje olarak Bağdat Paktı ile bölge devletlerinin bir araya gelerek hedefi SSCB'den gelebilecek muhtemel tehditlere karşı birlikte hareket etmek olan ve NATO ile de bağlantılı bir yapının kurulması amaçlanmıştır. Ancak sonuçları itibarıyla oldukça olumsuz bir Türkiye algısının ortaya çıkması ve bölge ülkeleri arasında çeşitli ihtilafların yaşanması söz konusu olmuştur. Bununla birlikte, Bağdat Paktı, Türkiye'nin hem coğrafi hem de tarihsel/kültürel olarak yakın bağlarının bulunduğu bölge ülkelerinin pek çoğuyla tamiri çok zor sorunlar yaşanmasına neden olmuştur.

Soğuk Savaş'ın en yoğun geçtiği dönem olarak kabul edilen 1950'li yıllar, pek çok önemli gelişmenin yaşandığı ve tarafların güvenlik önlemleri adına adımlar attığı bir dönem olmuştur. Bunların en önemlilerinden birisi de Ortadoğu bölgesinde ortak bir savunma birliği kurmak konusunda yaşanmıştır. Kore Savaşı sonrasında ABD tarafindan en fazla önem verilen bölgelerden birisi olan Ortadoğu'da, tarihsel süreklilikler gereği inisiyatifi elinde bulunduran İngiltere, bunun devamı için yukarıda da anlatıldığı üzere NATO'ya doğrudan bağlı olmayan ancak birlikte çalışabilecek bir Ortadoğu Komutanlı̆̆ı'nın kurulması için uğraşlar vermiştir. Türkiye de bu yapıya dahil olabileceğini ancak bunun NATO üyeliğini elde ettikten sonra mümkün olduğunu bildirmiştir.

Henüz Türkiye'nin üyelik süreci tamamlanmadan girişimlere başlayan İngiltere, 13 Ekim 1951 tarihinde ABD, Fransa, Türkiye ve Mısır'a davette bulunmuş ancak Mısır bu öneriyi reddedip İngiltere'yle olan 1936 tarihli Mısır'da İngiliz askerlerinin bulunmasını sağlayan anlaşmayı feshetmiştir. Bunun üzerine başarısızlığı uğrayan proje ortadan kalkmıştır (Oran, 2006: 619). Ancak ABD açısından bölgenin SSCB karşısında savunmasız bırakılması riskli bulunulduğundan, bu ülke öncülüğünde yeni arayışlara girilmiştir (Bostanc1, 2013: 173-174).

ABD'de bu sırada yaşanan başkanlık değiş̧imi ve yeni yönetimin bölgesel ittifaklar konusundaki bakış açısı belirleyici olmuştur. 1953 yılında göreve gelen Dwight D. Eisenhower (1953-1961), ABD’nin Ortadoğu politikasında yeniden yapılanmaya ihtiyaç olduğu düşüncesiyle çeşitli adımlar atmıştır ve Bağdat Paktı'na giden süreç böylelikle başlamıştır. ABD, bu süreçte İngiltere'ye nazaran bölge ülkeleri nezdindeki imajının olumsuz olmamasına güvenerek hareket etmiş ve başta Arap ülkeleri olmak üzere bölge devletlerinin bir savunma paktı etrafinda birleştirilmesine gayret etmiştir (Hale, 2000: 125). Bunun için ABD Dışişleri Bakanı John F. Dulles, 11-28 Eylül 1953 tarihleri arasında Mısır'dan başlayarak bütün Ortadoğu'yu kapsayacak bir geziye başlamış ve ortak savunma sistemi için zemin hazırlamaya çalışmışır. Dulles, geziden döndükten sonra böyle bir savunma mekanizması için ideal bir ortam olmadığını bakanlık raporunda belirtmiştir (Solak, 2019:130). Buna göre; "bölgede bir savunma teşkilatının kurulması yakın bir gelecekte mümkün görünmemekle birlikte bir ihtimal mevcuttur. Ancak Arap devletlerinin çoğunluğu İsrail’i 
Sovyetlere nazaran daha ciddi bir tehdit olarak görmektedirler. Yalnız 'Kuzey seddi' (Türkiye, Suriye, İran, Irak, Pakistan) ülkeleri olarak adlandırdığı SSCB'nin komşuları olan ülkeler bu tehlikenin farkındadırlar." Dulles'a göre böyle bir sistemin dış baskılarla kabul ettirilmesi mümkün değildir. Ancak bu devletlerin aynı tehdidi hissederek ortak kader duygusuyla ve kendi inisiyatifleriyle gerçekleştirmeleri mümkün olabilir (Kürkçüoğlu, 2010: 52-53).

Dulles'un raporu ve Eisenhower'ın yeni Ortadoğu politikası, Türkiye açısından bir firsat olarak algılanmıştır. Hem ekonomik gereksinimler (ABD'den daha fazla borç alma isteği) ve Türkiye'nin Batı ittifakı içerisindeki konumunu yükseltme isteği hem de bölgeyle olan tarihsel bağların kullanılarak ortak bir savunma teşkilatına öncülük etme hevesi Türkiye'nin Bağdat Paktı'nın kurulmasına giden sürece dahil olmasını sağlamıştır (Oran, 2006: 621). Türkiye, Dulles'un raporuna karşın Pakt'ın kurulması için beklemeden girişimlerde bulunmaya başlamıştır.

Türkiye, girişimlerine Pakistan'la başlamış ve bu ülkeyle 2 Nisan 1954'de Dostane İşbirliği Anlaşması imzalamıştır. Böylece ilk adım atılmıştır. Pakistan'dan sonra Türkiye, Arap olan ve Batı ile ilişkiler konusunda çok fazla sert bir tutum takınmayacak bir devlet arayışına girmiştir. Türkiye ile iyi ilişkilerine de güvenilen Irak, bu Pakt için ilk aday ülke olmuştur. Menderes öncülüğünde Türk yetkililer Irak'la yoğun temaslar kurmaya başlamıştır. Ancak Irak için iki önemli çekince söz konusu olmuştur. Birincisi, Pakt'a dahil olarak Batı ile işbirliğine başlanmasının İsrail'in durumunu kabul etmek olarak algılanması korkusu, diğeri de diğer Arap ülkeleri ile ilişkilerin bozulması riskiyle karşı karşıya kalmaktır. Ancak ABD'den gelen yardımların ülke ekonomisine katkısı ve bu süreçte İngiltere ve Mısır'ın Süveyş'teki İngiliz üssü konusunda anlaşmaya varmaları Irak'ın tavrını yumuşatmıştır. 12 Ocak 1955 tarihinde Menderes'in Irak ziyareti sırasında bir deklarasyon yayınlanarak bu iki ülkenin bir anlaşma kararına vardıkları bildirilmiştir. Buna göre, taraflar hem bölge içinden hem de bölge dışından gelebilecek tehditlere karşı birlikte hareket edeceklerdi. Böylelikle iki ülke diğer bölge devletlerine hem İsrail'in hem de SSCB'nin kastedilerek Pakta sicak bakmaları mesajını vermiştir. Ayrıca bu işbirliğine dahil olmak adına yalnızca coğrafi kıstas konmayarak ellerindeki imkanlarla bölge barışına katkı sağlayabilecek devletlere de açık kapı bırakılmıştır. Bunun temel hedefi İngiltere ve ABD'nin katılımına imkan sağlamak olmuştur (Kürkçüoğlu, 2010: 58-61).

Deklarasyonun yayınlanmasından sonra ciddi bir diplomasi atağına çıkan Menderes, 14 Ocak'ta hem Şam'a hem de Beyrut'a geçerek Suriye ve Lübnan'ın da Pakt'a dahil olmalarını teklif etmiştir. Ancak her iki ülke de Türkiye'nin beklediğinin aksine mesafeli bir tutum sergilemiş ve diğer bölge devletlerinin de üye olacağı bir yapıyı beklemişlerdir (Eroğul, 1998: 160). Bu sırada, 16 Ocak'ta Mısır' in Arap ülke liderlerini Türk-Irak anlaşmasıyla Arap birliğine "indirilen ciddi darbeyi” görüşmek üzere toplantıya davet etmesi, Mısır'ın konuya olan tavrını net bir biçimde ortaya koymuştur (Kürkçüoğlu, 2010: 62). Türkiye, bu konuda çeşitli girişimlerde bulunmakla birlikte, Irak dışında başka bir Arap devletini ikna edememiş ancak yine de 24 Şubat tarihinde Bağdat'ta deklorasyonda öngörülen yapının kurulduğu Türkiye-Irak Karşılıklı İşbirliği Antlaşması'nı ${ }^{8}$ imzalamıştır.

Bağdat Paktı kurulduktan sonra sırasıyla İngiltere (4 Nisan), Pakistan (23 Eylül) ve İran (3 Kasım 1955) üye olmuşlardır. Ancak beklenen diğer katılımlar gerçekleşmemiş ve başka bir bölge devleti Bağdat Paktı'na katılmamıştır (Hale, 2000: 126). Pakt'ın sonuçları genel olarak değerlendirildiğinde başarısız bir deneme olduğu söylenebilir. İlk olarak, Irak dışında bir Arap devletinin katılmaması bölgede bir ikili yapı ortaya çıkartmıştır. Bununla birlikte, Mısır, Suriye ve Suudi Arabistan bir araya gelerek yeni bir ittifak oluşturma yoluna gitmişlerdir (Gönlübol vd., 1996: 269). Irak ise Arap dünyasına ihanet etmekle itham edilmiş, 1958 Irak İhtilali'ne giden sürece girmiştir (Goldschmidt ve Davidson, 2008: 402). Diğer bölge devletlerinin güvenini kazanmak için anlaşmaya eklenen "bölge içerisinden gelebilecek tehditler" ifadesi nedeniyle İsrail sert tepki

\footnotetext{
${ }^{8}$ Antlaşma metni ve diğer açıklamalar için bkz. (Soysal, 1991: 489-493).
} 
göstermiş ve İngiltere ve ABD’ye baskı kurmaya başlamıştır. İngiltere'nin katılımı bağımsızlık mücadelelerini bu devlete karşı veren bölge devletleri için olumsuz bir hava yaratmıştır. ABD ise Pakt'a gözlemci olsa da üye olarak katılmayarak diğer üyelerin beklentilerini boşa çıkartmıştır (Kürkçüoğlu, 2010: 66-70).

Bağdat Paktı'nın kurulmasının en önemli sonuçlarından birisi, Pakt'ın SSCB'yi son derece rahatsız etmesi olmuştur. Batılı güçler tarafından bölgede askeri gruplaşmalar kurulduğunu iddia eden SSCB, Bağdat Paktı'nı eleştirmiştir (Bağc1, 2001: 67). Türkiye'nin tutumundan dolayı rahatsızlığını belirten SSCB, kendisine yöneltilen tehditler nedeniyle bölgeyle daha fazla ilgilenmeye başlamıştır. Özellikle Mısır'la iyi ilişkiler kurmaya çalışarak, bölge devletlerinin Batı karşıtı algılarını gündemde tutmaya çalışmıştır. Bu durum SSCB'ye ciddi avantajlar sağlamıştır (Yavuzalp, 1996: 81). Barışı tesis etmek için kurulan Bağdat Paktı, Soğuk Savaş mücadelesinin iki kutuplu yapısının bölgeye de hakim olması sonucunu doğurmuştur.

Bağdat Paktı'nın kurulmasının en ciddi olumsuz sonuçlarıyla karşılaşan ülkelerin başında Türkiye gelmiştir. Henüz 1952 yılında dönemin Dışişleri Bakanı Fuat Köprülü “'Ortadoğu bölgesinin kalkınması ve müdafaası için Batı ile işbirliği sağlamak Türkiye'nin vazifesidir” (Kürkçüoğlu, 2010: 72) şeklinde bir beyanda bulunarak Türkiye'nin kendisine biçtiği rolü açıklamıştır. Bu motivasyonla hareket eden Türkiye, başta Mısır olmak üzere Arap ülkeleriyle ilişkilerinde sorunlar yaşamıştır. Türkiye, Batı'nın sözcülüğünü yapmakla suçlanmış ve bağımsız bölge devletlerini kuracağı ittifaka dahil ederek ABD ve İngiltere'nin boyunduruğuna sokmaya çalışmakla itham edilmiştir. Türkiye'nin girişimlerine tepki gösteren Mısır ve Suriye, Bağdat Paktı'na karşı yeni bir Pakt hazırlıklarına girmiş ve bu süreç Türkiye'nin hem Suriye hem de Misır'la ilişkilerini olumsuz etkilemiştir (Kürkçüoğlu, 2010: 80). Bir de uluslararası sistemde üçüncü yol olarak görülebilecek bir yapının kurulması için toplanan Bandung Konferansı sırasında, Türkiye bu girişimleri eleştiren bir tavır takınmış ve diğer devletler Mısır öncülüğünde Türkiye'ye tepki göstererek yeni bir kutuplaşmanın kapısını açmıştır (Gönlübol vd., 1996: 273-276). Sonuç olarak, Bağdat Paktı, kurulma sürecinden imzaların atılmasına ve sonuçlarına kadar büyük ölçüde Türkiye'nin beklentilerini karşılamaktan uzak kalmış ve yarattığı olumsuz sonuçlar itibarıyla sonraki dönem ilişkilerini de etkilemiştir. Pakt'ın işlevi ve ömrü de buna bağlı olarak beklendiği gibi olmamıştır. 1958 yılında Irak İhtilali’nden sonra bu ülke ayrılmış ve Bağdat Paktı CENTO'ya dönmüştür. CENTO da 1979 yılında İran Devrimi'nden sonra dağılarak feshedilmiştir.

Bağdat Paktı ile ilgili olarak Menderes'in dış politika oluştururken izlediği yöntem büyük ölçüde Menderes'in uluslararası sistemi ve bölge dengelerini algılama şekliyle alakalı olmuştur. Türkiye'nin NATO üyesi tek bölge ülkesi olması ve aynı zamanda bölgeyle alakalı olarak sahip olduğu tarihsel bağlar, Ortadoğu'da ABD'nin de isteği olan bir güvenlik teşkilatının kurulması gerektiğini ve bunu da bir Batılı devlet değil Türkiye tarafindan yapılması gerektiği algisını yaratmıştır. Bu konuyla Türkiye'nin ilgilenmesinin diğer devletleri olumlu yönde etkileyeceğine inanan Menderes, yukarıda Köprülü'nün açıklamasında da değindiği üzere bu konuyu bir görev olarak görmüş ve israrcı bir politika izlemiştir. Dönemsel gelişmeler itibarıyla Mısır'ın ikna edilmesinin diğer devletler üzerinde etkili olacağı inancıyla bu devlete yoğunlaşılmış, Mısır'ın İngiltere'yle 1954 yılında yaptığı anlaşmaya fazla önem verilmiştir. Halbuki Mısır, bu anlaşmayla ülkedeki İngiliz baskısından kurtulmayı ve tam manasıyla bağımsız bir devlet olmayı amaçlamıştır. Menderes'in bu durumu yanlış yorumlaması, Bağdat Paktı konusunda ısrarını sürdürmesine ve sonucunda tamiri çok zor sorunların ortaya çıkmasına neden olmuştur. Ayrıca en uzun kara sınırının bulunduğu komşu ülke olan Suriye ile yaşanan krizler de Türkiye'nin sınır güvenliği noktasında sorunlar yaşamasına ve ilerleyen süreçte bu ülkede Sovyet tesirinin artmasına neden olmuştur. Tüm bu gelişmeler birlikte değerlendirildiğginde, Türkiye'nin dış kaynaklı gelişmeleri algılama konusunda önyargılı bir şekilde hareket ettiği ve bölgede kuvvetli bir birlik tesis etmeye çalışırken tersine sonuçlarla karşılaştığı bir durum söz konusu olmuştur. 


\section{Sonuç ve Değerlendirme}

Türkiye'nin kurumsal olarak da bir parçası olduğu Batı ile ilişkilerinin mihenk taşlarından bir tanesi şüphesiz ki Menderes dönemi olmuştur. Türkiye, Menderes döneminde henüz yeni ortaya çıkan Soğuk Savaş’ta Batı bloğunun lideri olan ABD'nin ciddi bir müttefiki olmuştur. Bir taraftan SSCB temelli algılanan tehditler, diğer yandan Menderes'in siyasi çizgisiyle birleşerek Türkiye'nin uzun vadeli dış politika ve güvenlik stratejilerinin temelleri atılmıştır. Bu sürecin temel belirleyici aktörü de dönemin başbakanı Adnan Menderes olmuştur.

Adnan Menderes dönemi Türk dış politikası genel olarak değerlendirildiğginde, liderin genel algılarının son derece belirleyici olduğu bir süreç ortaya çıkmaktadır. Batı yanlısı hatta "Amerikancı" olarak tabir edilen Menderes, dış politikasında sürekli olarak bu mantıkla hareket etmiştir. Batı'nın ihtiyaç duyduğu bir Türkiye portresi çizmeye çalışan ve dış politikasında bunu ispatlama gayretine giren Menderes, döneminin önemli dış politika olaylarını böyle yönetmeye çalışmıştır. Bu dönemde Batı ile ilişkileri ve kurumsal birlikteliği doruk noktasına ulaşan Türkiye, sonraki dönemlerde de sıklıkla bu miras üzerinden hareket etmiştir. Türkiye, çalışmada incelendiği üzere, Menderes döneminde yaşanan iki temel dış politika olayının sonuçlarından uzunca bir süreden beri etkilenmeye devam etmektedir. Bunlardan ilki olan NATO üyeliği, Türkiye'ye kapsamlı bir askeri güvenlik şemsiyesi sağlamış ve Türkiye, Soğuk Savaş dönemince geleneksel Rus tehdidini bertaraf edebilmiştir. Ayrıca askeri kapasitesini de ittifakla beraber yükseltebilen Türkiye'nin önemli bir askeri güç haline gelmesinde NATO da rol oynayan unsurlardan birisi olmuştur. Bununla birlikte, Türkiye'nin bariz bir ABD müttefiki olmasının bir takım olumsuz sonuçları da olmuş bilhassa özerk dış politika yürütülmesinde bu husus engelleyici sonuçlar doğurmuştur. Soğuk Savaş'ın geleneksel katı ittifak sistemleri Türkiye'nin de bu bağlamda hareket etmesini çoğu zaman zorunlu kılmış ve dış politikada genişbir etki alanı yaratılamamıştır. Sonuçları NATO'ya kıyasla daha kısa vadeli olmakla birlikte, Bağdat Paktı da Türk dış politikasında benzer şekilde etkiler doğurmuştur. Askeri ittifakın önemli bir üyesi haline gelen Türkiye'nin, Bağdat Paktı ile siyasi olarak da kendisini Batı ile özdeşleştirmesi anlamı yüklenen bu süreç, yine Türkiye'nin dış politika etki alanını kısıtlayıcı bir sonuç doğurmuştur. Bölgesel hassasiyetlere riayet etmemek ve Batı'nın bölgedeki sözcülüğünü yapmak suçlamalarıyla karşılaşan Türkiye, uzun yıllar bölgesel ilişkilerini dilediği gibi yürütememiştir.

21. yüzyılla birlikte, gelenekselleşen dış politika sınırlılıklarından kurtulma adına faaliyet yürütmek isteyen Türkiye'nin bu süreçte önüne çıkan temel sorunlar yukarıda da bahsedildiği üzere fazlasıyla Batı temelli bir dış politika geçmişi olmuştur. Türkiye, bu kimliğinde sıyırılabilmek adına ciddi bir gayret göstermekle birlikte, yaşanan krizler (Türkiye ile ilgili ya da değil) sürece sürekli olarak zarar vermiş ve önemli ilerleme sağlanamamıştır. Yüzyılın ilk çeyreğinin sonlarına yaklaşıldığı bir dönemde, Türk dış politikası yine benzer meseleler ve sorunlarla muhatap olmak durumunda kalmıştır. Bir taraftan ABD müttefikliğinin sorgulanması ancak diğer yandan da bölgesel oluşumların önündeki tarihsel engeller, Türkiye'nin uzun vadeli dış politika hedeflerinin önünde engeller yaratmaktadır.

Söz konusu bu sürecin temellerinin başta NATO üyeliği ve Bağdat Paktı girişimleri gibi dış politika olayları olmak üzere Menderes döneminde atıldığı bir gerçektir. Sonraki 60 yıllık dış politika tarihine bariz etkiler doğuran ve büyük ölçüde Menderes'in inisiyatifleriyle şekillenen bu dönemde Türkiye, Batı bloğuna dahil olmak ve ittifakın önemli bir parçası haline gelebilmek için önemli bir gayret göstermiştir. Bu bağlamda, 2010'lu yıllarla birlikte başlayan Türkiye'nin başta ABD olmak üzere Batı müttefikliğinin sorgulanması dönemi analiz edilirken hikayenin başlangıcına yeniden bakmak önemli görünmektedir. Türkiye ve Batı ittifakı ilişkilerinin analizi çalışmalarına bu çerçeveden yaklaşmanın kapsamlı değerlendirmeler için önemli bir gereklilik olduğu düşünülmektedir. 


\section{Kaynakça}

Ahmad, F. Ve Turgay, B. A. (1976). Türkiye'de Çok Partili Politikanın Açıklamalı Kronolojisi 19451971. Ankara: Bilgi Yayınları.

Akşin, A. (1991). Atatürk’ün dış politika ilkeleri ve diplomasisi. Ankara: Türk Tarih Kurumu Basımevi.

Bağcı, H. (2001). Türk dış politikasında 1950'li yıllar. (2. Baskı). Ankara: METU Press.

Bilge-Criss, N. (2012). "Türkiye-NATO ittifakının tarihsel boyutu”. Uluslararası İlişkiler. 9(34): 128.

Bostancı, M. (2013). "Türk-Arap İlişkilerine Etkisi Bakımından Bağdat Paktı”. Gazi Akademik Bakıs. 7(13): 171-184.

Crockatt, R. (1995). The fifty years war: the United States and the Soviet Union in world politics, 1941-1991. New York: Routledge.

Eroğul, C. (1998). Demokrat Parti tarihi ve ideolojisi. (3. Bask1). Ankara. İmge Kitabevi.

Esmer, A. Ş. ve Sander, O. (1996). “İkinci Dünya Savaşı'nda Türk dış politikası”. Olaylarla Türk dış politikası (1919-1995). (Ed.) M. Gönlübol. (9. Bask1). Ankara: Siyasal Kitabevi.

Goldschmidt, A. J. ve Davidson, L. (2008). Kısa Ortadoğu tarihi. (Çev.). A. Güler. İstanbul: Doruk Yayınları.

Göktepe, C. Ve Seydi, S. (2015). “Soğuk Savaş Başlangıcında Türk Dış Politikası”. Bilig, 22: 197222.

Gönlübol, M., Ülman, H., Bilge, S. ve Sezer, D. (1996). “İkinci Dünya Savaşı’ndan sonra Türk dış politikası”. Olaylarla Türk dış politikası (1919-1995). (Ed.) M. Gönlübol. (9. Bask1). Ankara: Siyasal Kitabevi.

Hale, W. (2000). Turkish foreign policy 1774-2000. London: Frank Cass Publishers.

Harper, J. L. (2011). The Cold War. New York: Oxford University Press.

Hogan, M. J. (1987). The Marshall Plan: America, Britain, and the reconstruction of Western Europe 1947-1952. New York: Cambridge University Press.

Kürkçüoğlu, Ö. (2010). Türkiye'nin Arap Ortadoğu'suna karşı politikası (1945-1970). Ankara: Barış Kitap.

Oran, B. (Editör) (2006). Türk dlş politikası: kurtuluş savaşından bugüne olgular, belgeler ve yorumlar cilt I: 1919-1980. (12. Baskı). İstanbul: İletişim Yayınları.

Sewell, M. (2002). The Cold War. Cambridge: Cambridge University Press.

Sibley, K. A. S. (1998). The Cold War. Westport, Conn: Greenwood Press.

Solak, M. (2019). "Türkiye’nin güvenlik politikası çerçevesinde Bağdat paktı". Yakın Dönem Türkiye Araştırmaları. 35: 125-145.

Soysal, İ. (1991). Türkiye'nin uluslararası siyasal bağıtları cilt II (1945-1990) kesim A (çok taraflı bağıtlar). Ankara: Atatürk Kültür, Dil ve Tarih Yüksek Kurumu Yayınları XVI. Dizi - Sa. 38.

Tuncer, H. (2013). Menderes'in dış politikası Batı'nın güdümündeki Türkiye. İstanbul: Kaynak Yayınları. 
Wenger, A. ve Zimmermann, D. (2003). International relations: from the Cold War to the globalized world. Boulder, Colo.: Lynne Rienner.

Yavuzalp, E. (1996). Liderlerimiz ve dlş politika bir diplomat gözüyle. Ankara: Bilgi Yayınevi.

Yetener, M. (2007). “Adnan Menderes”. Türk dış politikasında liderler. (Ed.) A. F. Demir. Ankara: Bağlam Yayınları.

Yıldız, M. (2007). "1945-1960 Dönemi hazırlanan yabanc1 raporların Türk sanayi politikalarına etkileri”. Turkish Studies. 12(31): 303-318.

Young, J. W. ve Kent, J. (2013). International relations since 1945: a global history. Oxford: Oxford University Press. 